\title{
Hubungan Bobot Telur dengan Bobot Tetas dan Bobot Tetas dengan Bobot Badan Ayam Merawang G1 sampai Umur 4 Bulan
}

\section{The Relationship Between Egg Weight with Hatching Weight and Hatching Weight with Body Weight G1 of Merawang Chicken Aged up to 4 Months}

\author{
M. Sari, Depison*, Gushariyanto, \& E. Wiyanto \\ Program Studi Peternakan Fakultas Peternakan Universitas Jambi \\ Jl. Jambi-Muara Bulian KM 15 Mendalo Indah Jambi 36361 \\ *Email korespondensi: depison.nasution@unja.ac.id
}

\author{
- Diterima: 29 Juli 2021 • Direvisi: 21 September 2021 • Disetujui: 22 September 2021
}

\begin{abstract}
ABSTRAK. Penelitian ini bertujuan untuk mengetahui hubungan bobot telur dengan bobot tetas dan bobot tetas dengan bobot badan, pertambahan bobot badan dan penciri ukuran dan bentuk tubuh ayam Merawang jantan dan betina (G1) sampai umur 4 bulan. Metode penelitian adalah metode eksperimen. Materi penelitian yaitu telur ayam Merawang sebanyak 315 butir, menghasilkan 174 ekor ayam Merawang yang terdiri 68 ekor jantan dan 106 ekor betina. Data yang dihimpun meliputi: bobot telur, bobot tetas, bobot badan umur 1-4 bulan serta pertambahan bobot badan dan ukuranukuran tubuh. Perbedaan rataan bobot telur, bobot tetas, bobot badan serta pertambahan bobot badan dianalisis menggunakan Uji-t. Analisis Regresi dan Korelasi digunakan untuk melihat hubungan dan keeratan hubungan antara bobot telur dengan bobot tetas dan bobot tetas dengan bobot badan dari umur 1-4 bulan. Analisis komponen utama digunakan untuk mengidentifikasi penciri bentuk dan ukuran tubuh. Pengolahan data menggunakan perangkat lunak statistika Minitab versi 18. Hasil penelitian ini menunjukkan bahwa rataan bobot telur, bobot tetas, bobot badan, pertambahan bobot badan dan ukuran-ukuran tubuh ayam Merawang jantan berbeda nyata $(\mathrm{P}<0,05)$ lebih tinggi dibandingkan dengan ayam Merawang betina. Bobot telur berpengaruh nyata terhadap bobot tetas dan bobot tetas berpengaruh nyata terhadap bobot badan umur 1 hari - 4 bulan. Keeratan hubungan bobot telur dengan bobot tetas serta bobot tetas dengan bobot badan umur 1 hari - 4 bulan positif dan signifikan. Penciri ukuran tubuh pada ayam Merawang jantan dan betina yaitu lingkar dada, sedangkan penciri bentuk tubuh yaitu panjang tubuh atas dan panjang dada.
\end{abstract}

Kata kunci : Ayam Merawang, bobot telur, bobot badan,regresi, korelasi.

ABSTRACT. This study aims to determine the relationship between egg weight and hatching weight and hatching weight with body weight, body weight gain, and the size and shape of male and female Merawang chickens (G1) until the age of 4 months. The research method is an experimental method. The research material is Merawang chicken eggs as many as 315 eggs were hatched -174 Merawang chickens consisting of 68 males and 106 females. The data collected included: egg weight, hatching weight, bodyweight aged 1-4 months as well as body weight gain and body measurements. Differences in average egg weight, hatching weight, body weight, and body weight gain were analyzed using the t-test. Regression and Correlation Analysis was used to see the relationship and the close relationship between egg weight and hatching weight and hatching weight and body weight from 1-4 months of age, principal component analysis was used to identify body shape and size markers. Data processing used statistical software Minitab version 18. The results of this study showed that the average egg weight, hatching weight, body weight, body weight gain, and body sizes of male Merawang chickens were significantly different $(P<0.05)$ higher than that of male Merawang chickens. Chasing female. Egg weight had a significant effect on hatching weight and hatching weight had a significant effect on body weight at the age of 1-4 months. The close relationship between egg weight and hatching weight and hatching weight with bodyweight at 1-4 months of age were positive and significant. Body size markers in male and female Merawang chickens were chest circumference, while body shape markers were upper body length and chest length.

Keywords: Merawang Chicken, egg weight, body weight, regression, correlation.

\section{PENDAHULUAN}

Indonesia merupakan negara tropis yang memiliki keanekaragaman plasma nutfah yang berlimpah. Salah satu plasma nutfah yang dimiliki yaitu ternak ayam lokal. Ayam lokal memiliki potensi cukup baik untuk dikembangkan menjadi bibit unggul dalam 
upaya menunjang ketahanan pangan dan meningkatkan kesejahteraan peternak. Umumnya ayam lokal di Indonesia dipelihara secara ekstensif. Indonesia sampai saat ini memiliki 32 jenis ayam lokal (ecotype) dan masing-masing jenis memiliki keunggulan tersendiri (Nuraini et al., 2018). Diantara sekian banyak jenis ayam lokal yang cukup potensial untuk dikembangkan adalah ayam Merawang.

Ayam Merawang merupakan ayam lokal yang berasal dari Desa Merawang Kecamatan Merawang Kabupaten Bangka, Propinsi Kepulauan Bangka Belitung dan merupakan sumber genetik serta aset masyarakat Propinsi Kepulauan Bangka Belitung berdasarkan SK Mentan No. 2846/Kpts./LB.430/8/2012. Ayam Merawang merupakan salah satu ayam lokal yang berasal dari spesies Gallus-gallus, family Phasianidae yang berpotensi dikembangkan menjadi ayam pedaging dan sekaligus ayam petelur dengan produksi telur mencapai 125 butir/tahun (Nataamijaya, 2010). Ayam Merawang memiliki produktivitas lebih rendah jika dibandingkan dengan ayam Kampung dan ayam Sentul (Irmaya et al., 2021), produktivitas ayam Merawang dapat dilihat dari bobot badan dan pertambahan bobot badan. Salah satu upaya yang dapat dilakukan untuk meningkatkan produktivitas ayam Merawang yaitu melalui seleksi.

Seleksi adalah suatu proses memilih ternak yang memiliki mutu genetik yang lebih baik untuk dikembangkan. Seleksi merupakan dasar utama pemuliaan ternak yang dilakukan untuk meningkatkan mutu genetik menjadi lebih baik (Nurgiartiningsih et al., 2017). Umumnya seleksi dilakukan berdasarkan bobot badan, sehingga memerlukan waktu yang cukup lama, untuk mempersingkat waktu seleksi dapat dilakukan seleksi dini. Seleksi dini dapat dilakukan melalui seleksi telur, seleksi telur merupakan upaya untuk menghasilkan bibit yang unggul, bobot telur diduga mempunyai hubungan yang erat dengan bobot tetas (Okatama et al., 2018). Bobot tetas diduga memiliki hubungan yang erat dengan bobot badan.

Sifat kuantitatif dapat digunakan untuk mengetahui tingkat produktivitas ternak, identifikasi dan penentu penciri pada ternak yang mencakup ukuran dan bentuk. Identifikasi karakterisitik fenotip menggunakan analisis komponen utama bertujuan untuk menentukan penciri dan bentuk tubuh (Mahmudi et al., 2019). Karakteristik kuantitatif dapat dilihat melalui: panjang fermur, panjang tibia, panjang maxilla, panjang sayap, panjang tarsometatarsus, lingkar tarsometatarsus, tinggi jengger, panjang jari ketiga (tengah), panjang sternum, dan bobot badan (Ashifudin et al., 2017).

Berdasarkan uraian di atas perlu untuk dilakukan penelitian tentang hubungan bobot telur dengan bobot tetas dan bobot tetas dengan bobot badan ayam Merawang G1 sampai umur 4 bulan.

\section{MATERI DAN METODE}

Materi penelitian ini adalah 315 butir telur dan 174 ekor ayam Merawang. Peralatan yang digunakan adalah alat tulis, jangka sorong digital, timbangan digital kapasitas $3 \mathrm{~kg}$ dengan ketelitian 0,1, kamera digital, pita ukur, lampu pijar, tempat pakan dan tempat minum, pakan komersil BR 1 untuk umur 0-1 bulan dan BR 2 untuk umur 1-4 bulan, kandungan nutrisi BR1 adalah energi $3020-3120 \mathrm{Kkal} / \mathrm{kg}$, protein 22$23 \%$, lemak min 5\%, kalsium $\min 0,9 \%$ dan pospor min $0,6 \%$, sedangkan pada BR2 adalah energi $4100 \mathrm{Kkal} / \mathrm{kg}$, protein $20-21 \%$, lemak $\min 5 \%$, kalsium $\min 0,9 \%$ dan pospor $\min$ $0,6 \%$, vaksin dan obat-obatan serta mesin tetas yang digunakan 2 mesin tetas dengan kapasitas 200 butir. Penelitian ini menggunakan metode eksperimen (pengamatan secara langsung).

Proses pembentukan generasi pertama (G1) yaitu dengan cara melakukan seleksi terhadap indukan (G0) sebesar $20 \%$ jantan dan $36 \%$ betina, sehingga diperoleh indukan 
sebanyak 10 ekor jantan dan 36 ekor betina. Ayam yang telah diseleksi dipelihara di dalam kandang ukuran $2 \times 1,8 \mathrm{~m}^{2}$ dengan rasio jantan dan betina 1:6 dan diberi pakan BR 1P secara adlibitum. Sistem perkawinan pada tetua yaitu secara alami. Proses pengumpulan telur dilakukan selama 6 hari berturut-turut per periode penetasan, penetasan dilakukan sebanyak 2 periode.

Telur yang terkumpul ditimbang dengan berat berkisar antara $38-45 \mathrm{~g}$, setiap telur diberi kode angka pada ujung telur sebagai penanda telur dan kode A, B, dan C pada setiap sisi telur untuk mempermudah dalam proses pemutaran telur saat diinkubasi. Telur dimasukkan ke dalam mesin tetas, sisi yang diberi kode huruf A berada pada bagian atas, telur diinkubasi selama \pm 21 hari. Hari ketiga dilakukan pemutaran telur sebanyak 3 kali sehari, dari A ke B, B ke C, C ke A dan seterusnya. Proses pemutaran dilakukan pada pukul 07.00, 14.00 dan 21.00 WIB. Peneropongan dilakukan sebanyak 3 kali, pertama dilakukan pada hari ke-5 untuk penentuan telur fertil dan infertil, kemudian dilakukan penoropongan pada hari ke 10 dan hari ke 15 bertujuan untuk mengetahui perkembangan embrio. Telur fertil ditunjukkan dengan adanya pembuluh darah seperti jaring laba-laba dengan bintik ditengah, sedangkan telur infertil dikeluarkan dari mesin tetas. Dari 315 butir telur yang ditetaskan, diperoleh telur fertil sebanyak 255 butir dan telur yang menetas sebanyak 181 butir sehingga menghasilkan 181 DOC jantan 71 ekor dan betina 110 ekor. Anak ayam yang baru menetas dipelihara dengan sistem pemeliharaan di dalam kandang koloni dengan pemberian pakan dan minum secara terus-menerus (adlibitum), pemeliharaan dilakukan sampai umur 4 bulan dengan angka mortalitas sebesar 3,9\%. Penimbangan bobot badan, pertambahan bobot badan dilakukan pada setiap bulan dan pengukuran ukuran tubuh dilakukan pada bulan ke-3. Setiap ayam yang diukur diberi tanda berupa nomor pada bagian sayap.
Peubah yang diamati dalam penelitian ini yaitu :

1. Bobot telur bobot hasil penimbangan telur dengan menggunakan timbangan digital (g).

2. Bobot badan diukur dengan cara menimbang ayam dengan timbangan digital (g).

3. Pertambahan bobot badan didapatkan dengan cara menghitung selisih akhir dengan selisih awal berat ayam Merawang:

$$
\mathrm{PBB}=\mathrm{BB} \text { akhir- BB awal }
$$

4. Panjang Paruh (PP) jarak antara pangkal maxilla sampai ujung maxilla, yang diukur dengan jangka sorong digital (mm).

5. Lebar Paruh (LP) diukur dari pinggir paruh bagian luar sebelah kiri dan kanan, dengan menggunakan jangka sorong digital ( $\mathrm{mm}$ ).

6. Panjang Kepala (PK) diukur dari pangkal paruh hingga kepala bagian belakang, menggunakan jangka sorong digital (mm).

7. Lingkar kepala (LK) diukur pada bagian kepala yang paling tinggi dengan menggunakan pita ukur (mm).

8. Tinggi Kepala (TK) diukur pada bagian kepala yang paling tinggi dengan menggunakan jangka sorong digital (mm).

9. Panjang Leher (PL) diukur dari tulang first cervical vetebrae sampai dengan last cervical vetebrae menggunakan jangka sorong digital(mm).

10. Lingkar Leher (LL) melingkarkan pita ukur di leher (mm).

11. Panjang Sayap (PSa) diukur dari tulang humerus sampai ujung phalanges menggunakan pita ukur (mm).

12. Panjang Tubuh Atas (PTA) pangkal leher sampai pangkal ekor menggunakan pita ukur (mm).

13. Panjang Tubuh Bawah (PTB) diukur dari tulang dada sampai pubis (mm). 
14. Tinggi Tubuh (TT) diukur dari bagian bawah ayam berpijak sampai bagian atas punggung menggunakan pita ukur (mm).

15. Panjang Dada (PDa), pengukuran panjang dada (sternum) dilakukan dari ujung dada bagian depan sampai ujung bagian belakang menggunakan pita ukur ( $\mathrm{mm}$ ).

16. Lebar Dada (LDa) pengukuran lebar dada diperoleh dengan mengukur jarak dari tulang sternum bagian kiri hingga bagian kanan (yang paling lebar) menggunakan jangka sorong digital ( $\mathrm{mm}$ ).

17. Lingkar Dada (LiDa) pengukuran lingkar dada diperoleh dengan mengukur jarak dari tulang sternum bagian kiri kembali ke tulang sternum bagian kiri menggunakan pita ukur (mm).

18. Panjang Shank (PS) diukur sepanjang tulang tarsometatarsus (shank) menggunakan jangka sorong digital (mm).

19. Lingkar Shank (LS) melingkari pita ukur pada bagian tengah tulang tarsometatarsus (shank).

20. Panjang Tibia (Pti) diukur dari patella sampai ujung tibia diukur dengan menggunakan jangka sorong digital $(\mathrm{cm})$.

21. Lingkar Tibia (Lti) melingkarkan pita ukur pada tibia $(\mathrm{mm})$.

22. Panjang Jari Ketiga (PJK) diukur dari pangkal sampai ujung jari ketiga di ukur menggunakan jangka sorong digital (mm).

23. Jarak Tulang Pubis (JTP) diukur menggunakan jangka sorong digital ( $\mathrm{mm})$.

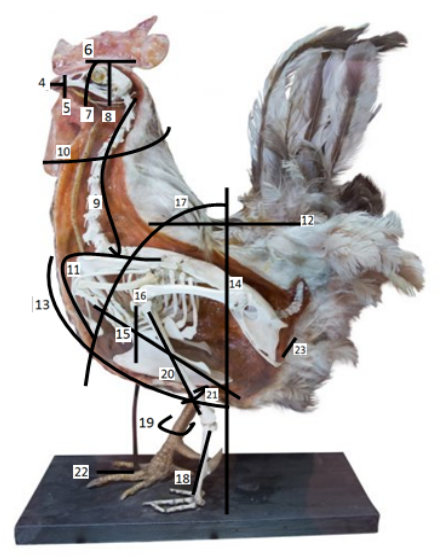

Gambar 1: Bagian Tubuh yang Diukur

\section{Analisis Data}

Uji beda rata-rata digunakan untuk melihat perbedaan bobot telur, bobot badan, pertambahan bobot badan dan ukuran-ukuran tubuh antara ayam Merawang jantan dan betina serta perbandingan pertambahan bobot badan antara periode umur dianalisis menggunakan Uji-t (Gaspersz, 2006).

Rumus Uji-t (Gaspersz, 2006):

$$
\mathrm{t}=\frac{\bar{X}_{1}-\bar{X}_{2}}{\sqrt{\frac{\sum\left(X_{J 1}-\bar{X}_{1}\right)^{2}}{n_{1}\left(n_{1}-1\right)}+\frac{\sum\left(X_{J 2}-\bar{X}_{2}\right)^{2}}{n_{2}\left(n_{2}-1\right)}}}
$$

Keterangan :

$\mathrm{t} \quad=$ nilai $\mathrm{t}$ hitung

$\bar{X}_{1} \quad=$ rataan sampel pada ayam jantan,

$\bar{X}_{2} \quad$ rataan sampel pada ayam betina,

$X_{j 1} \quad=$ nilai pengamatan ke-J pada ayam jantan

$X_{j 2} \quad=$ nilai pengamatan ke-J pada ayam betina

$\mathrm{n}_{1} \quad$ = jumlah sampel pada ayam jantan, dan

$\mathrm{n}_{2} \quad$ = jumlah sampel pada ayam betina.

Kaidah Keputusan :

Terima Ho bila t-hitung $\leq \mathrm{t}$-tabel

Terima H1 bila t-hitung $>$ t-tabel

Analisis regresi adalah analisis untuk melihat hubungan antara bobot telur dengan bobot tetas dan bobot tetas dengan bobot badan pada umur 1,2,3 dan 4 bulan.Di analisis secara parsial menggunakan model regresi menurut Gaspersz (2006).

$$
\mathrm{Y}_{1}=\mathrm{b}_{0}+\mathrm{b}_{1} \mathrm{x}
$$

Keterangan:

$\mathrm{Y}_{1}=$ Bobot tetas/Bobot badan

$\mathrm{b}_{0}=$ Konstanta

$b_{1}=$ Koefisien regresi dari bobot telur/bobot tetas

$\mathrm{X}=$ Bobot telur dan bobot tetas

Analisis korelasi digunakan untuk melihat keeratan hubungan antara bobot telur dengan bobot tetas dan bobot tetas dengan bobot badan pada umur 1 bulan, 2 bulan, 3 bulan dan 4 bulan. Analisis dilakukan 
berdasarkan rumus menurut Gaspersz (2006) sebagai berikut:

$$
r_{x y}=\frac{n \sum x_{i} y_{i}-\left(\sum x_{i}\right)\left(\sum y_{i}\right)}{\sqrt{\left\{n \sum x_{1}^{2}-\left(\sum x_{i}\right)^{2}\right\}}\left\{n \sum y_{2}^{1}-\left(\sum y_{i}\right)^{2}\right\}}
$$

\section{Keterangan:}

$$
\begin{array}{ll}
r_{x y} & =\text { Korelasi Pearson } \\
\mathrm{x} & =\text { Bobot tetas/Bobot badan } \\
\mathrm{y} & =\text { Bobot telur/bobot tetas }
\end{array}
$$

\section{Analisis Komponen Utama}

Analisis Komponen Utama (AKU) untuk menentukan penciri ukuran dan penciri bentuk jantan betina ayam Merawang (G1).

AKU adalah teknik statistik yang digunakan pada sekumpulan data yang saling berkorelasi. Tujuannya ialah untuk menemukan sejumlah variabel yang koheren dalam subkelompok, yang secara relatif independen terhadap yang lain. Perbedaan ukuran dan bentuk tubuh yang diamati dianalisis berdasarkan AKU. Persamaan ukuran dan bentuk diturunkan dari matriks kovarian. Model matematika yang digunakan untuk analisis ini (Gaspersz, 2006) sebagai berikut:

$$
Y j=a_{1 j} X_{1}+a_{2 j} X_{2}+a_{3 j} X_{3}+\ldots \ldots+a_{7 j} X
$$

Keterangan :

$Y_{j} \quad=$ komponen utama ke-j $(j=1,2 ; 1=$ ukuran, 2 = bentuk )

$\mathrm{X}_{1,2,3 \ldots}=$ peubah $\mathrm{ke} 1,2,3 \ldots .7$

$a_{i j, 2,2,3 j, . .}=$ vektor eigen variable ke-i $(1,2,3, \ldots .7)$ dan Komponen utama ke j.

Pengolahan data dibantu dengan menggunakan perangkat lunak statistika yaitu Minitab versi 18.

\section{HASIL DAN PEMBAHASAN}

\section{Rataaan bobot telur dan bobot badan ayam Merawang}

Rataan bobot telur dan bobot badan ayam Merawang umur 1 hari, 1 bulan, 2 bulan, 3 bulan dan 4 bulan disajikan pada tabel 1 .

Tabel 1. Bobot telur dan bobot badan ayam Merawang jantan dan betina

\begin{tabular}{lcrr}
\hline \multirow{2}{*}{\multicolumn{1}{c}{ Variabel }} & \multicolumn{3}{c}{ Ayam Merawang } \\
\cline { 2 - 4 } & \multicolumn{1}{c}{ Gabungan } & Jantan & \multicolumn{1}{c}{ Betina } \\
\hline Bobot Telur (g/ekor) & $42,93 \pm 3,71^{\mathrm{a}}$ & $43,67 \pm 3,06^{\mathrm{a}}$ & $42,18 \pm 2,59^{\mathrm{b}}$ \\
Bobot Tetas (g/ekor) & $31,81 \pm 2,85^{\mathrm{b}}$ & $33,97 \pm 2,73^{\mathrm{a}}$ & $29,96 \pm 1,16^{\mathrm{c}}$ \\
Bobot badan 1 Bulan (g/ekor) & $291,65 \pm 35,42^{\mathrm{b}}$ & $320,28 \pm 32,97^{\mathrm{a}}$ & $267,21 \pm 9,96^{\mathrm{c}}$ \\
Bobot badan 2 Bulan (g/ekor) & $647,78 \pm 63,46^{\mathrm{b}}$ & $700,96 \pm 47,13^{\mathrm{a}}$ & $602,37 \pm 32,86^{\mathrm{c}}$ \\
Bobot badan 3 Bulan (g/ekor) & $1038,81 \pm 105,07^{\mathrm{b}}$ & $1127,17 \pm 65,12^{\mathrm{a}}$ & $963,33 \pm 66,57^{\mathrm{c}}$ \\
Bobot badan 4 Bulan (g/ekor) & $1193,75 \pm 111,62^{\mathrm{b}}$ & $1294,15 \pm 60,96^{\mathrm{a}}$ & $1108 \pm 62,14^{\mathrm{c}}$ \\
\hline
\end{tabular}

Keterangan: Superskrip yang berbeda pada baris yang sama berarti berbeda nyata $(\mathrm{P}<0,05)$.

Tabel 1.menunjukkan bahwa rataan bobot telur ayam Merawang jantan dan betina pada penelitian ini lebih tinggi dibandingkan dengan hasil penelitian Nuraini et al. (2016) yang menyatakan bahwa rataan bobot telur ayam Merawang adalah sebesar 40,42 $\pm 5,85$ g. Rataan bobot telur ayam Merawang berkisar antara 3845 g/butir (BPTU Sembawa, 2002). Perbedaan ini diduga karena adanya pengaruh pakan, umur induk dan lingkungan. Hal ini sesuai dengan pendapat Tugiyanti et al. (2012) yang menyatakan bahwa bobot telur dapat dipengaruhi oleh pakan, umur induk dan lingkungan.

Hasil analisis uji beda rata-rata menunjukkan bahwa bobot telur ayam Merawang yang menghasilkan bobot tetas dengan jantan berbeda nyata $(\mathrm{P}<0,05)$ dengan bobot telur yang menghasilkan bobot tetas dengan betina. Perbedaan bobot telur antara ayam jantan dan betina diduga karena adanya perbedaan jumlah albumen. Hal ini sesuai pendapat Mahi dan Muharlien (2013) yang menyatakan bahwa besar kecilnya telur 
dipengaruhi oleh kromosom yang melewati magnum, magnum akan mensekresikan albumen dalam humlah banyak pada kromosom $x x$ dan mensekresikan albumen dalam jumlah sedikit pada kromosom xy.
Grafik bobot badan ayam Merawang jantan betina G1 umur 1 hari, 1 bulan, 2 bulan, 3 bulan dan 4 bulan disajikan pada Gambar 1 .

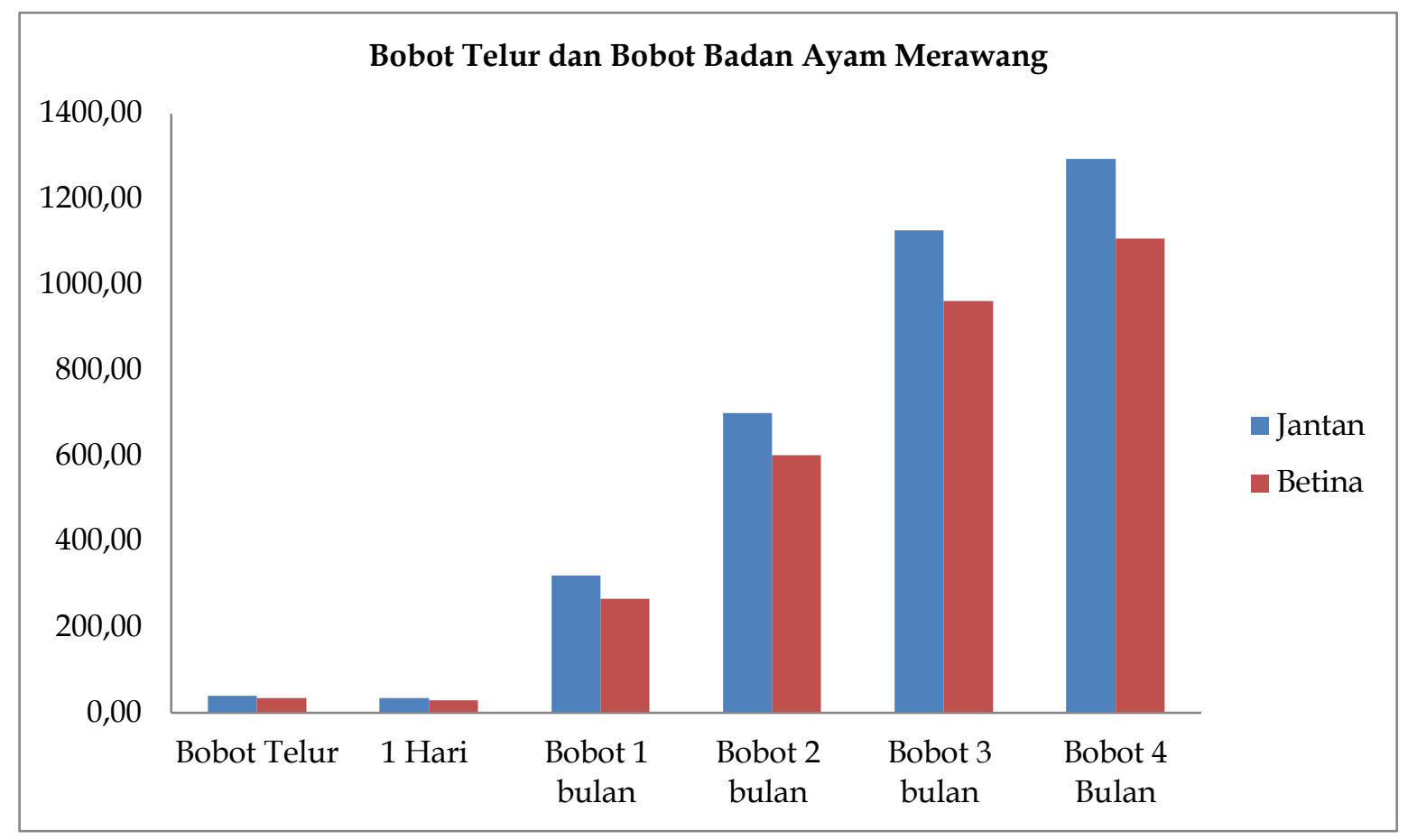

Gambar 1. Bobot badan ayam Merawang

Tabel 1. menunjukkan bahwa rataan bobot badan ayam Merawang jantan dan betina hasil penelitian ini lebih tinggi dibandingkan dengan beberapa hasil penelitian. Mulhazaa et al. (2020) menyatakan bahwa bobot badan ayam Merawang jantan dan betina umur 3 bulan adalah 919,1 g dan 719,9 g. Rataan bobot badan ayam Merawang umur 1 hari, 1, 2, 3 dan 4 bulan secara berurutan yaitu 31,06 g, 204,96 g, $556,45 \mathrm{~g}, 858,20 \mathrm{~g}$ dan 1071,14 g (Irmaya et al., 2020) Adanya perbedaan bobot badan diduga karena pengaruh lingkungan dan genetik. Hal ini sesuai dengan pendapat Risnajati (2014) yang menyatakan bahwa perbedaan bobot badan diduga karena pengaruh faktor genetik, kondisi lingkungan serta manajamen pemeliharaan.

Hasil uji beda rata-rata menunjukkan bahwa rataan bobot badan ayam Merawang jantan umur 1 hari, 1 bulan, 2 bulan, 3 bulan dan 4 bulan berbeda nyata $(\mathrm{P}<0,05)$ lebih tinggi dibandingkan dengan rataan bobot badan ayam Merawang betina. Adanya perbedaan bobot badan antara ayam Merawang jantan dan betina pada penelitian ini diduga karena adanya perbedaan hormon testosterone yang di hasilkan oleh testis yang hanya dimiliki ternak jantan. Hal ini sesuai dengan pendapat Pagala et al. (2019) menyatakan bahwa pada ayam jantan gen hormon pertumbuhan mengontrol sifat produksi lebih tinggi dibandingkan ayam betina.

\section{Pertambahan bobot badan}

Rataan pertambahan bobot badan ayam Merawang jantan dan betina disajikan pada Tabel 2. 
Tabel 2. Pertambahan bobot badan ayam Merawang jantan dan betina.

\begin{tabular}{|c|c|c|c|c|}
\hline \multirow[b]{2}{*}{ Uraian } & \multicolumn{4}{|c|}{ Umur Ayam Merawang } \\
\hline & $\begin{array}{c}1 \text { hari -1bulan } \\
\text { (g/ekor/bln) }\end{array}$ & $\begin{array}{l}\text { 1-2 bulan } \\
\text { (g/ekor/bln) }\end{array}$ & $\begin{array}{c}\text { 2-3 bulan } \\
\text { (g/ekor/bln) }\end{array}$ & $\begin{array}{c}\text { 3-4 bulan } \\
\text { (g/ekor/bln) }\end{array}$ \\
\hline Gabungan & $259,84 \pm 32,73^{c}$ & $356,13 \pm 33,49^{b}$ & $391,03 \pm 52,46^{a}$ & $154,94 \pm 27,96^{\mathrm{d}}$ \\
\hline Jantan & $286,30 \pm 30,54 c$ & $380,67 \pm 23,24^{b}$ & $426,21 \pm 30,26^{a}$ & $166,97 \pm 26,69 d$ \\
\hline Betina & $237,24 \pm 8,92^{c}$ & $335,16 \pm 25,80^{b}$ & $360,95 \pm 48,69 a$ & $144,67 \pm 24,97 \mathrm{~d}$ \\
\hline
\end{tabular}

Keterangan: Superskrip yang berbeda pada baris yang sama bearti berbeda nyata (P < 0,05), Superskrip yang berbeda pada kolom yang sama bearti berbeda nyata $(\mathrm{P}<0,05)$.

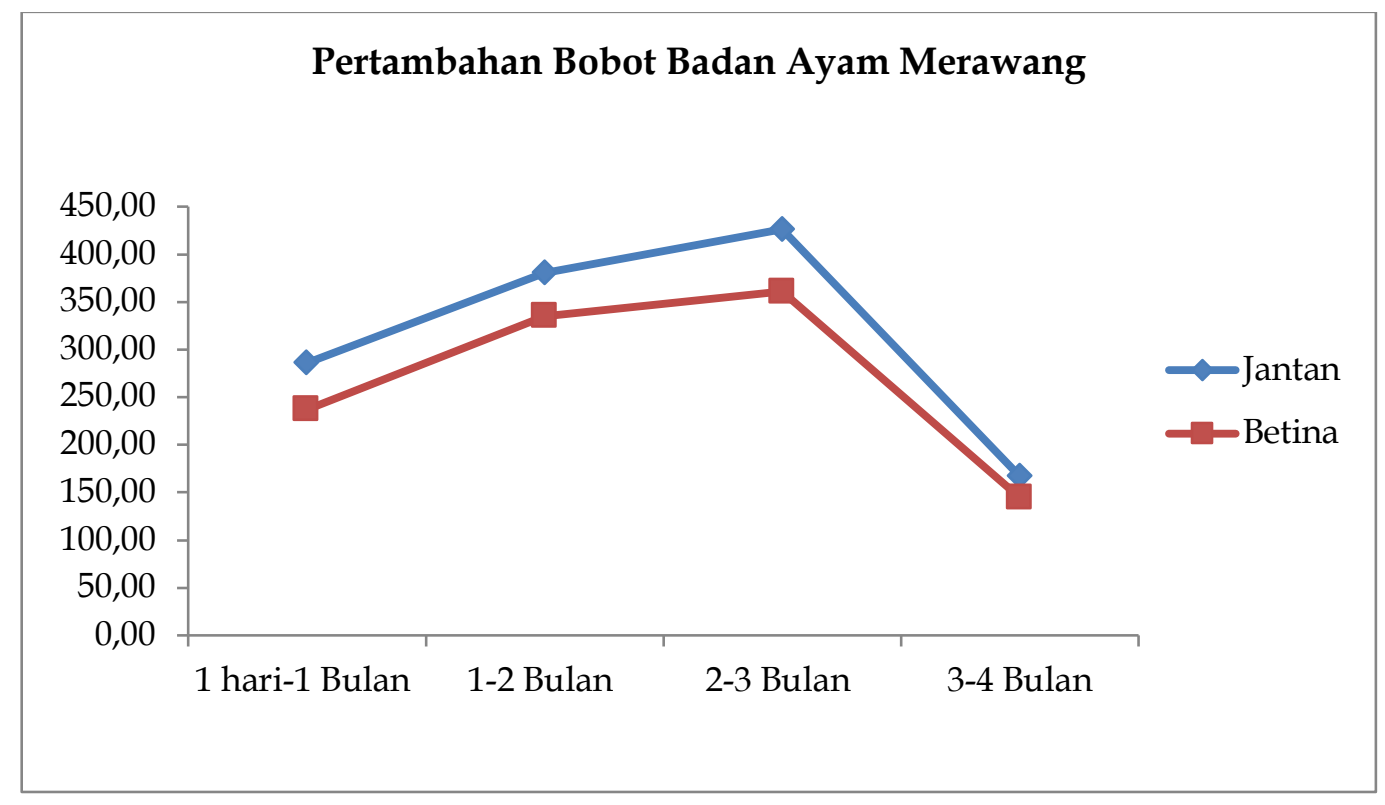

Gambar 2. Pertambahan bobot badan ayam Merawang jantan dan betina

Tabel 2. Menunjukkan bahwa rataan pertambahan bobot badan ayam Merawang jantan dan betina umur 1 hari-1 bulan, 1-2 bulan, 2-3 bulan dan 3-4 bulan lebih tinggi dibandingkan dengan penelitian Mulhazaa et al. (2020) yang menyatakan bahwa rataan pertambahan bobot badan ayam Merawang umur 1 hari-1 bulan dan 1-2 bulan yaitu 109,87g dan 140,73g. Irmaya et al. (2021) yang menyatakan bahwa rataan pertambahan bobot badan ayam Merawang umur 2-3 bulan yaitu 301,75. Adanya perbedaan pertambahan bobot badan diduga karena faktor genetik, manajemen pemeliharaan dan pakan. Hal ini sesuai dengan pendapat Qurniawan (2016) yang menyatakan bahwa pertambahan bobot badan dipengaruhi oleh genetik, lingkungan, manajemen pemeliharaan, kualitas dan kuantitas pakan yang dikonsumsi.
Pertambahan bobot badan umur 2-3 bulan berbada nyata $(\mathrm{P}<0,05) \quad$ lebih tinggi dibandingkan pertambahan bobot badan umur 1 hari-1 bulan, 1-2 bulan dan 3-4 bulan. Pertambahan bobot badan umur 1-2 bulan berbeda nyata $(\mathrm{P}<0,05)$ lebih tinggi dibandingkan pertambahan bobot badan umur 1 hari-1 bulan dan 3-4 bulan. Pertambahan bobot badan umur 1 hari - 1 bulan berbeda nyata $(\mathrm{P}<0,05)$ lebih tinggi dibandingkan pertambahan bobot badan umur 3-4 bulan. Artinya pertambahan bobot badan tertinggi dicapai pada umur 2-3 bulan dan terjadi penurunan pertambahan bobot badan pada umur 3-4 bulan. Penurunan pertambahan bobot badan umur 3-4 bulan diduga karena mulai terjadi proses pematangan saluran reproduksi ternak menjelang dewasa kelamin. Hal ini sesuai dengan pendapat Trisiwi (2017) yang 
menyatakan bahwa ayam pada umur 12 hingga 20 minggu akan mengalami penurunan pertambahan bobot badan. Menurut Agustina et al. (2013) masa peningkatan pertambahan bobot badan terjadi sebelum ternak mengalami pubertas (dewasa kelamin) dan mengalami penurunan pada saat ternak menuju proses dewasa kelamin.
Regresi bobot telur dengan bobot tetas dan bobot tetas dengan bobot badan 1,2,3 dan 4 bulan

Persamaan regresi bobot telur dengan bobot tetas dan bobot tetas dengan bobot badan ayam Merawang jantan dan betina disajikan pada tabel 3.

Tabel 3. Persamaan regresi bobot telur dengan bobot tetas dan bobot tetas dengan bobot badan pada umur 1, 2, 3 dan bulan.

\begin{tabular}{lll}
\hline Uraian & Variabel & Persamaan \\
\hline \multirow{3}{*}{ Jantan } & Bobot Telur - Bobot tetas & $\mathrm{Y}=-1,83+0,8200 \mathrm{X}$ \\
& Bobot tetas - BB 1 Bulan & $\mathrm{Y}=-47,6+10,829 \mathrm{X}$ \\
& Bobot tetas - BB 2 Bulan & $\mathrm{Y}=188,5+15,08 \mathrm{X}$ \\
& Bobot tetas - BB 3 Bulan & $\mathrm{Y}=488,6+18,80 \mathrm{X}$ \\
& Bobot tetas - BB 4 Bulan & $\mathrm{Y}=736,6+16,41 \mathrm{X}$ \\
\hline & Bobot Telur - Bobot tetas & $\mathrm{Y}=11,897+0,4283 \mathrm{X}$ \\
& Bobot tetas - BB 1 Bulan & $\mathrm{Y}=35,1+7,747 \mathrm{X}$ \\
& Bobot tetas - BB 2 Bulan & $\mathrm{Y}=-125,7+24,30 \mathrm{X}$ \\
& Bobot tetas - BB 3 Bulan & $\mathrm{Y}=-400+45,52 \mathrm{X}$ \\
& Bobot tetas - BB 4 Bulan & $\mathrm{Y}=-104+40,46 \mathrm{X}$ \\
\hline
\end{tabular}

Hasil analisis regresi menunjukkan bahwa bobot telur ayam Merawang jantan dan betina berpengaruh nyata $(\mathrm{P}<0,05)$ terhadap bobot tetas ayam Merawang jantan dan betina. Persamaan regresi antara bobot telur dengan bobot tetas ayam Merawang jantan dan betina pada penelitian ini adalah $Y=-1,83+0,8200 X$ dan $Y=11,897+0,4283 X$. Persamaan regresi di atas menggambarkan bahwa setiap kenaikan $1 \mathrm{~g}$ bobot telur maka akan berdampak pada kenaikan bobot tetas sebesar 0,8200 pada jantan dan 0,4283 pada betina. Hal ini sesuai dengan pendapat Okatama et al. (2018) menyatakan bahwa setiap kenaikan $1 \mathrm{~g}$ bobot telur maka terjadi kenaikan bobot tetas sesuai dengan koefisiennya. Artinya besar kecilnya bobot telur akan mempengaruhi bobot tetas ayam Merawang.

Berdasarkan Tabel 3, hasil analisis regresi menunjukkan bahwa bobot tetas ayam Merawang jantan dan betina berpengaruh nyata $(\mathrm{P}<0,05)$ terhadap bobot badan ayam Merawang jantan dan betina umur 1,2,3 dan 4 bulan.
Persamaan regresi bobot tetas dengan bobot badan ayam Merawang jantan umur 1,2,3 dan 4 bulan secara berurutan $Y=-47,6+10,829 X$, $\mathrm{Y}=188,5+15,08 \mathrm{X}, \quad \mathrm{Y}=488,6+18,80 \mathrm{X} \quad$ dan $Y=736,6+16,41 X$. Persamaan regresi bobot tetas dengan bobot ayam Merawang betina umur 1,2,3 dan 4 bulan secara berurutan $\mathrm{Y}=35,1+7,747 \mathrm{X}, \quad \mathrm{Y}=-125,7+24,30 \mathrm{X}, \quad \mathrm{Y}=-$ $400+45,52 X$ dan $Y=-104+40,46 X$. Nilai koefisien regresi tersebut menggambarkan bahwa setiap kenaikan bobot tetas akan mempengaruhi kenaikan bobot badan umur 1,2,3 dan 4 bulan sebesar koefisiennya.

Korelasi bobot telur dengan bobot tetas dan bobot tetas dengan bobot badan 1,2,3 dan 4 bulan

Nilai koefisien korelasi bobot telur terhadap bobot tetas sebesar 0,919 pada jantan dan 0,952 pada betina. Koefisien korelasi bobot telur terhadap bobot tetas baik pada jantan dan betina menunjukkan korelasi positif tinggi. Pengaruh bobot telur terhadap bobot tetas sebesar $84,4 \%$ pada jantan dan 90,6\% pada 
betina. Hal ini sesuai dengan pendapat Okatama et al. (2018) yang menyatakan nilai korelasi positif menunjukkan bahwa korelasi yang terjadi antara bobot telur dengan bobot tetas adalah hubungan yang berbanding lurus yang berarti semakin besar bobot telur, maka semakin besar bobot tetas.

Tabel 4. Korelasi bobot telur dengan bobot tetas dan bobot tetas dengan bobot badan 1, 2, 3 dan 4 bulan ayam Merawang.

\begin{tabular}{ccccc}
\hline \multirow{2}{*}{ Variabel } & \multicolumn{2}{c}{ Jantan } & \multicolumn{2}{c}{ Betina } \\
\cline { 2 - 5 } & $\mathbf{R}$ & $\mathbf{R}^{\mathbf{2}}$ & $\mathbf{R}$ & $\mathbf{R}^{\mathbf{2}}$ \\
\hline Bobot Telur-Bobot tetas & 0,919 & 0,844 & 0,952 & 0,906 \\
Bobot tetas -BB 1 bln & 0,898 & 0,806 & 0,907 & 0,822 \\
Bobot tetas -BB 2 bln & 0,875 & 0,765 & 0,863 & 0,744 \\
Bobot tetas -BB 3 bln & 0,789 & 0,622 & 0,798 & 0,636 \\
Bobot tetas -BB 4 bln & 0,736 & 0,541 & 0,759 & 0,576 \\
\hline
\end{tabular}

Keterangan : $r=$ Korelasi $r^{2}=$ Determinasi

Nilai koefisien korelasi bobot tetas terhadap bobot badan umur 1 bulan, 2 bulan, 3 bulan dan 4 bulan ayam Merawang jantan secara berurut 0,$898 ; 0,875 ; 0,789 ; 0,736$ dan betina secara berurut 0,$907 ; 0,863 ; 0,798$ dan 0,759 . Koefisien korelasi bobot tetas terhadap bobot badan ayam Merawang baik pada jantan dan betina menunjukkan korelasi positif tinggi. Tingginya koefisien korelasi dapat diartikan bahwa bobot tetas erat hubungannya terhadap bobot badan umur 1 bulan, 2 bulan, 3 bulan dan 4 bulan. Hal ini sesuai dengan penelitian Pamungkas et al. (2013) yang menyatakan bahwa bobot badan dapat dipengaruhi oleh bobot tetas. Pengaruh bobot tetas terhadap bobot badan dapat dilihat berdasarkan nilai determinasi $\left(\mathrm{r}^{2}\right)$. Pengaruh bobot tetas terhadap bobot badan umur 1 bulan, 2 bulan, 3 bulan dan 4 bulan berturut-turut untuk jantan dan betina adalah sebesar $80,6 \% ; 76,5 \% ; 62,2 \% ; 54,1 \%$ dan $82,2 \% ; 74,4 \% ; 63,6 \% ; 57,6 \%$.

\section{Ukuran-ukuran tubuh ayam Merawang}

Berdasarkan Tabel 5. Hasil uji beda ratarata menunjukkan bahwa ukuran-ukuran tubuh ayam Merawang jantan berbeda nyata $(\mathrm{P}<0,05)$ lebih tinggi dibandingkan dengan ayam Merawang betina. Artinya ayam Merawang jantan memiliki kerangka ukuran-ukuran tubuh yang lebih besar sehingga memiliki performa lebih tinggi dibandingkan ayam Merawang betina. Hikmawaty et al. (2014) menyatakan bahwa ukuran tubuh ternak dapat berbeda antara satu sama lain yang kemungkinan adanya perbedaan tersebut disebabkan potensi genetik, lokasi asal, serta sistem pemeliharaan dan perkawinan yang diterapkan.

Perbedaan ukuran-ukuran tubuh ternak ini diduga akibat adanya pengaruh genetik ternak karena kondisi lingkungan dan perlakuan saat penelitian sudah diusahakan sama, maka perbedaan nyata ukuran-ukuran tubuh ayam Merawang jantan dan betina disebabkan oleh keragaman genetik ternak. Lukmanudin et al. (2018) menyatakan bahwa keragaman pada ternak dapat bersumber dari keragaman genetiknya, dimana keragaman genetik bisa disebabkan oleh gen aditif, gen terbanyak dan gen epistasis.

\section{Persamaan ukuran dan bentuk tubuh ayam Merawang}

Berdasarkan hasil persamaan ukuran pada Tabel 6 dapat diketahui bahwa keragaman total komponen utama ke-1 ternak ayam Merawang jantan dan betina mempunyai keragaman total secara berurutan $51,8 \%$ dan 95,8\%, dengan nilai Eigen 10, 35, 19,15. Keragaman total komponen utama ke-2 yang disetarakan dengan bentuk pada ternak ayam Merawang jantan dan betina secara berurutan adalah 8,3\% dan 1,9\% dengan nilai Eigen 1,66 
dan 0 ,38. Persentase ini merupakan proporsi keragaman terbesar di antara komponen utama yang diperoleh. Hasil analisis komponen utama adalah angka pada PC1 dan PC2. Menurut
Kurnianto et al. (2013) menyatakan bahwa PC1 dapat diartikan sebagai vektor ukuran dan PC2 dapat diartikan sebagai vektor bentuk.

Tabel 5. Ukuran-ukuran tubuh ayam Merawang jantan dan betina

\begin{tabular}{|c|c|c|}
\hline \multirow{2}{*}{$\begin{array}{l}\text { Ukuran } \\
\text { Tubuh }\end{array}$} & \multicolumn{2}{|c|}{ Merawang } \\
\hline & Jantan & Betina \\
\hline PPa (mm) & $45,78 \pm 1,04^{\mathrm{a}}$ & $41,26 \pm 0,68^{b}$ \\
\hline PKe (mm) & $42,22 \pm 1,40^{a}$ & $41,97 \pm 1,24^{b}$ \\
\hline LPa (mm) & $8,32 \pm 0,53^{a}$ & $8,13 \pm 0,39 b$ \\
\hline TKe (mm) & $34,61 \pm 2,87 a$ & $32,73 \pm 0,90^{b}$ \\
\hline LKe (mm) & $116,39 \pm 5,62^{a}$ & $120,20 \pm 4,98^{\mathrm{b}}$ \\
\hline PaLe (mm) & $148,38 \pm 12,83^{a}$ & $144,71 \pm 6,30^{\mathrm{b}}$ \\
\hline LiLe (mm) & $95,79 \pm 5,62^{a}$ & $95,43 \pm 4,28^{b}$ \\
\hline PSa (mm) & $220,88 \pm 10,26^{a}$ & $206,18 \pm 9,72^{\mathrm{b}}$ \\
\hline PTA (mm) & $292,14 \pm 11,45^{a}$ & $208,95 \pm 9,72^{\mathrm{b}}$ \\
\hline PTB (mm) & $303,116 \pm 14,13^{a}$ & $286,02 \pm 9,75^{\mathrm{b}}$ \\
\hline TB (mm) & $338,57 \pm 18,10^{a}$ & $327,61 \pm 12,37 \mathrm{~b}$ \\
\hline PD (mm) & $136,01 \pm 2,54^{a}$ & $140,53 \pm 6,37 \mathrm{~b}$ \\
\hline $\mathrm{LD}(\mathrm{mm})$ & $70,10 \pm 2,35^{\mathrm{a}}$ & $69,30 \pm 1,92^{b}$ \\
\hline LiD (mm) & $330,57 \pm 22,42^{a}$ & $319,31 \pm 9,31^{b}$ \\
\hline PS (mm) & $88,66 \pm 2,95^{a}$ & $86,15 \pm 4,96^{b}$ \\
\hline LiS (mm) & $47,69 \pm 2,93^{a}$ & $47,94 \pm 1,56^{b}$ \\
\hline PTi (mm) & $142,85 \pm 7,12^{\mathrm{a}}$ & $141,14 \pm 7,04^{\mathrm{b}}$ \\
\hline LiTi (mm) & $115,13 \pm 6,71^{a}$ & $107,79 \pm 4,50^{\mathrm{b}}$ \\
\hline PJK (mm) & $65,11 \pm 2,42^{\mathrm{a}}$ & $63,53 \pm 2,92^{b}$ \\
\hline JTP (mm) & $14,82 \pm 0,39 a$ & $15,14 \pm 0,33^{b}$ \\
\hline
\end{tabular}

Keterangan : Huruf yang berbeda pada baris yang sama berbeda nyata $(\mathrm{P}<0,05)$

$\mathrm{PPa}=$ Panjang Paruh, $\mathrm{PKe}=$ Panjang Kepala, $\mathrm{LPa}=$ Lebar Paruh, $\mathrm{TKe}=$ Tinggi Kepala, LKe $=$ Lingkar Kepala, PaLe $=$ Panjang Leher, LiLe $=$ Lingkar Leher, $\mathrm{PSa}=$ Panjang Sayap, PTA $=$ Panjang Tubuh Atas, $\mathrm{PTB}=$ Panjang Tubuh Bawah, $\mathrm{TT}=$ Tinggi Tubuh, $\mathrm{PD}=$ Panjang Dada, $\mathrm{LD}$ $=$ Lebar Dada, $\mathrm{LiD}=$ Lingkar Dada, $\mathrm{PS}=$ Panjang Shank, LiS = Lingkar Shank, $\mathrm{PTi}=$ Panjang Tibia, LiTi $=$ Lingkar Tibia, PJK = Panjang Jari Ketiga, JTP = Jarak Tulang Pubis.

Variabel komponen utama tertinggi dalam persamaan ukuran tubuh pada ayam Merawang jantan dan betina adalah lingkar dada artinya lingkar dada dapat dijadikan penentu ukuran tubuh pada ayam Merawang jantan dan betina karena memiliki kontribusi terbesar terhadap persamaan ukuran tubuh. Menurut Mariandayani et al. (2013) bahwa dalam analisis komponen utama, parameter fenotipik dapat digunakan untuk menentukan parameter morfometrik yang menunjukkan penanda bangsa dan disebut sebagai peubah pembeda bangsa.
Variabel komponen utama tertinggi yang diperoleh dalam persamaan penciri bentuk tubuh ayam Merawang jantan adalah PTA sedangkan pada ayam Merawang betina adalah PD. Perbedaan ini diduga disebabkan oleh adanya perbedaan genetik. Menurut Putri et al. (2020) bahwa bentuk tubuh ayam sangat dipengaruhi oleh genetik, sedangkan ukuran tubuh selain dipengaruhi genetik juga dipengaruhi oleh lingkungan atau topografi daerah, tujuan pemeliharaan serta perawatan ayam. 
Tabel 6. Persamaan ukuran dan bentuk tubuh ayam Merawang jantan dan betina

\begin{tabular}{|c|c|c|c|c|c|}
\hline Jenis & & & Persamaan & KT (\%) & $\lambda$ \\
\hline \multirow{4}{*}{$\begin{array}{l}\text { Ayam } \\
\text { Merawang }\end{array}$} & \multirow{2}{*}{ Jantan } & $\begin{array}{l}\text { Ukuran } \\
\text { Tubuh }\end{array}$ & $\begin{aligned} &-0,164 \mathrm{PP}+0,11 \mathrm{LP}+0,094 \mathrm{PK}+-0,251 \mathrm{TK}+ \\
& 0,235 \mathrm{LiK}+0,249 \mathrm{PL}+0,239 \mathrm{LiL}+0,268 \mathrm{PSa}+ \\
&=0,242 \mathrm{PTa}+0,252 \mathrm{PTb}+0,28 \mathrm{Tt}+0,201 \mathrm{PD}+ \\
& 0,265 \mathrm{LD}+0,287 \mathrm{LiD}+0,08 \mathrm{PS}+0,267 \mathrm{LiS}+ \\
& 0,265 \mathrm{PTi}+0,252 \mathrm{LiTi}+0,194 \mathrm{PJK}+-0,022 \mathrm{JTP}\end{aligned}$ & 51,8 & 10,357 \\
\hline & & $\begin{array}{l}\text { Bentuk } \\
\text { Tubuh }\end{array}$ & $\begin{aligned} & -0,589 \mathrm{PP}+-0,231 \mathrm{LP}+-0,214 \mathrm{PK}+-0,354 \mathrm{TK}+ \\
& 0,016 \mathrm{LiK}+-0,195 \mathrm{PL}+-0,011 \mathrm{LiL}+0,026 \mathrm{PSa}+ \\
= & \mathbf{0 , 3 6 7 P T a}+-0,182 \mathrm{PTb}+-0,03 \mathrm{Tt}+-0,05 \mathrm{PD}+- \\
& \text { 0,022LD + -0,144LiD + -0,411 PS + -0,009LiS + } \\
& -0,33 \mathrm{PTi}+-0,028 \mathrm{LiTi}+-0,058 \mathrm{PJK}+0,085 \mathrm{JP}\end{aligned}$ & 8,3 & 1,663 \\
\hline & \multirow{2}{*}{ Betina } & $\begin{array}{l}\text { Ukuran } \\
\text { Tubuh }\end{array}$ & $\begin{array}{ll} & 0,212 \mathrm{PP}+0,224 \mathrm{LP}+0,221 \mathrm{PK}+0,225 \mathrm{TK}+ \\
& 0,224 \mathrm{LiK}+0,224 \mathrm{PL}+0,225 \mathrm{LiL}+0,225 \mathrm{PSa}+ \\
= & 0,225 \mathrm{PTa}+0,226 \mathrm{PTb}+0,224 \mathrm{Tt}+0,213 \mathrm{PD}+ \\
& 0,226 \mathrm{LD}+0,227 \mathrm{LiD}+0,225 \mathrm{PS}+0,224 \mathrm{LiS}+ \\
& 0,226 \mathrm{PTi}+-0,225 \mathrm{LiTi}+0,225 \mathrm{PJK}+-0,225 \mathrm{JTP}\end{array}$ & 95,8 & 19,152 \\
\hline & & $\begin{array}{l}\text { Bentuk } \\
\text { Tubuh }\end{array}$ & $\begin{aligned} & 0,503 \mathrm{PP}+-0,144 \mathrm{LP}+-0,373 \mathrm{PK}+-0,029 \mathrm{TK}+ \\
& 0,199 \mathrm{LiK}+-0,186 \mathrm{PL}+-0,2 \mathrm{LiL}+-0,029 \mathrm{PSa}+ \\
& \text { 0,029 PTa + -0,052 PTb + 0,27Tt + 0,521PD + } \\
& \text { 0,18LD + -0,12LiD + 0,211 PS + -0,098LiS + } \\
& \text { 0,063PTi + 0,062LiTi + 0,04 PJK + 0,112 JTP }\end{aligned}$ & 1,9 & 0,388 \\
\hline
\end{tabular}

Keterangan : PP = Panjang Paruh, LP $=$ Lebar Paruh, $\mathrm{PK}=$ Panjang Kepala, $\mathrm{TK}=$ Tinggi Kepala, $\quad$ LiK $=$ Lingkar Kepala, PL = Panjang Leher, LiL = Lingkar Leher, PSa $=$ Panjang Sayap, $\mathrm{PTa}=$ Panjang Tubuh Atas, PTb = Panjang Tubuh Bawah, Tt $=$ Tinggi Tubuh, $\mathrm{PD}=$ Panjang Dada, $\mathrm{LD}=$ Lebar Dada, PS = Panjang Shank, LiS = Lingkar Shank, PTi = Panjang Tibia, LiTi = Lingkar Tibia, PJK = Panjang Jari Ketiga, JTP = Jarak Tulang Pubis.

\section{KESIMPULAN}

Berdasarkan hasil penelitian dapat disimpulkan bahwa rataan bobot telur, bobot tetas, bobot badan, pertambahan bobot badan dan ukuran ukuran tubuh ayam Merawang jantan lebih tinggi dibandingkan dengan ayam Merawang betina. Pertambahan bobot badan tertinggi pada penelitian ini terjadi pada umur 2-3 bulan. Terdapat hubungan antara bobot telur dengan bobot tetas dan bobot tetas dengan bobot badan ayam Merawang baik pada ayam jantan maupun ayam betina yang bernilai positif. Nilai korelasi tertinggi bobot tetas dengan bobot badan ayam Merawang jantan dan betina adalah bobot umur 1 bulan. Penciri ukuran tubuh pada ayam Merawang jantan dan betina yaitu lingkar dada. Penciri bentuk pada ayam Merawang jantan dan betina yaitu panjang tubuh atas dan panjang dada.

\section{KONFLIK KEPENTINGAN}

Penulis menyatakan bahwa tidak memiliki konflik dan kepentingan.

\section{UCAPAN TERIMA KASIH}

Ucapan terimakasih penulis sampaikan kepada Fakultas Peternakan dan Universitas Jambi yang telah memberikan fasilitas dan dukungan dalam penelitian.

\section{DAFTAR PUSTAKA}

Agustina, D., N. Iriyanti dan S. Mugiyono. 2013. Pertumbuhan dan konsumsi pakan pada berbagai jenis Itik lokal betina yang pakannya disuplementasi probiotik. Jurnal Ilmiah Peternakan. 1:691-698. 
Ashifudin, E. Kurnianto, dan Sutopo, 2017. Karakteristik morfometrik ayam kedu jengger merah dan jengger hitam generasi pertama di satker ayam maron-temanggung. Jurnal Ilmu Ternak. 17:40-46.

Balai Pembibitan Ternak Unggul Sembawa. 2002. Panduan Teknis Pemuliaan Ayam Lokal. Direktorat Jenderal Bina Produksi Peternakan. Balai Pembibitan Ternak Unggul Sembawa Sumatera Selatan. Pertemuan Pembibitan Regional, 2 Juli 2002.

Gaspersz, V. 2006. Teknik Analisis dalam Penelitian Percobaan. Tarsito. Bandung.

Hikmawaty., A. Gunawan., R. R. Noor, dan Jakaria. 2014. Identifikasi ukuran tubuh dan bentuk tubuh sapi bali di beberapa pusat pembibitan melalui pendekatan analisis komponen utama. Jurnal Ilmu Produksi dan Teknologi Hasil Peternakan. 2:231-237.

Irmaya, D., Depison, dan Gurhairiyanto. 2021. Quantitative characteristic of indonesian native chickens at the age of 4 months. Anim. Res. 19:108-119.

Kurnianto, E., S. Sutopo., E. Purbowati., E.T. Setiatin., D. Samsudewa, and T. Permatasari. 2013. Multivariate analysis of morfphological traits of local goats in Central Java-Indonesia. Iran. J. App. Anim. Sci. 3:361- 367.

Lukmanudin, M., Sumantri, C., Darwati, S., 2018. Ukuran tubuh ayam Lokal Silangan IPB D-1 generasi kelima umur 2 sampai 12 minggu. Jurnal Ilmu Produksi dan Teknologi Hasil Peternakan. 6:113-120.

Mahi, M.A dan Muharlien. 2013. Pengaruh bentuk telur dan bobot telur terhadap jenis kelamin, bobot tetas dan lama menetas burung puyuh (Coturnix. Coturnix Japonica). J. Ternak Tropika. 14:32-44.

Mahmudi, M., R. Priyanto dan J. Jakaria. 2019. Karakteristik morfometrik sapi aceh, sapi PO, dan sapi bali berdasarkan analisis komponen utama (AKU). Jurnal Ilmu Produksi dan Teknologi Hasil Peternakan. 7:17-26.

Mariandayani, H.N., D. Duryadi. S. Sulandari, dan C. Sumantri. 2013. Keragaman fenotipik dan pendugaan jarak genetik pada ayam lokal dan ayam broiler menggunakan analisis morfologi. Jurnal Veteriner. 14:475-484.

Mulhazaa, R., T. Saili, dan R. Badaruddin, 2020. Karakteristik Pertumbuhan dan Mortalitas Beberapa Strain Ayam Lokal. JIPHO. 2:2081908.

Nataamijaya, A.G. 2010. Pengembangan potensi ayam lokal untuk menunjang peningkatan kesejahteraan petani. Jurnal Litbang Pertanian. 29:131-138.

Nuraini, Z. Hidayat, dan K. Yolanda. 2018. Performa bobot badan akhir, bobot karkas serta persentase karkas ayam merawang pada keturunan dan jenis kelamin yang berbeda. Sains Peternakan. 16:69-73.

Nuraini, Hidayat Z, Adrial. 2016. Produksi dan karakteristik telur ayam merawang dengan system pemeliharaan secara intensif di Kebun Percobaan Petaling Kepulauan Bangka Belitung. Prosiding Seminar Nasional Inovasi Teknologi Pertanian. Banjarbaru (ID): BPTP Kalsel. Hal 155

Nurgiartiningsih, A. 2017. Pengantar Parameter Genetik Pada Ternak. Cetakan Pertama.UB Press, Malang.

Okatama, M. S., S. Maylinda, dan V. M. A. Nurgiartiningsih. 2018. Hubungan bobot telur dan indeks telur dengan bobot tetas itik dabung di kabupaten Bangkalan. Jurnal Ternak Tropika. 19:1-8.

Pamungkas, R.S., Ismoyowati, dan S.A. Santosa. 2013. Kajian bobot tetas, bobot badan umur 4 dan 8 minggu serta korelasinya pada berbagai itik lokal dan itik manila jantan. Jurnal Ilmiah Peternakan. 1:488 - 500.

Pagala, M.A., A. S. Aku, R. Badaruddin, dan H. Has. 2018. Karakteristik fenotip dan genotip gen GH (growth hormon) pada ayam tolaki. Jurnal Ilmu dan Teknologi Peternakan Tropis. 5:1-4.

Putri, A.B.S.R.N.,Gushairiyanto dan Depison. 2020. Bobot badan dan karakteristik morfometrik beberapa galur ayam lokal. Jurnal Ilmu dan Teknologi Peternakan Tropis. 7:256-263.

Risnajati, D 2014. Pengaruh Jumlah Ayam Per Induk Buatan terhadap Performan Ayam Petelur Strain Isa Brown Periode Starter. Sains Peternakan. 12:10-14. 
Trisiwi, H.F., 2017. Pengaruh level protein pakan pada masa pertumbuhan terhadap penampilan pada awal peneluran ayam betina hasil persilangan ayam kampung jantan dan ayam ras petelur betina. Jurnal Ilmu dan Teknologi Hasil Ternak. 12:61-68.

Tugiyanti E,.dan I. Ning. 2012. Kualitas Eksternal Telur Ayam Petelur yang Mendapat Ransum dengan Penambahan Tepung Ikan Fermentasi
Menggunakan Isolasi Prosedur Antihistamin. Jurnal Aplikasi Teknologi Pangan. 1:44-47.

Qurniawan, A., I. I. Erief, \& R. Afnan. 2016. Performans Produksi Ayam Pedaging pada Lingkungan Pemeliharaan dengan Ketinggian yang Berbeda di Sulawesi Selatan. Jurnal Veteriner. 17:622-633. 